Palotás Zsolt PhD

palotasz@gmail.com

történész (Szeged)

\title{
Kapcsolatok oszmán Észak-Afrika és a nyugat-európai államok között $(1605-1704)^{1}$
}

- Relations between Ottoman North Africa and
the Western European Powers (1605-1704) -

AвStRaCt In the 17th century the vassal/tributary states or Regencies of the Ottoman Empire in North Africa, namely Algiers, Tunis and Tripoli and the Western European States maintained active political and economic relations because of the so-called Muslim piracy or corsairing. The Dutch Republic, because of her commercial interests preferred the peaceful negotiations with the Ottoman's Maghrebian subjects, and accepted that the peace had to be redeemed with regular tribute. In contrast, England chose to use her naval power to achieve the protection of the merchant ships. Over a period of fourteen months, the British navy sank 30 pirate ships which was enough to conclude peace treaties with the Regencies. France chose an even more brutal approach to protect her commercial and political interests than the British. The military operations against Algiers and Tunis in the 1680 s were rather sieges than sea battles.

As a consequence of the activities of the western renegades and paradoxically to piracy, North Africa was integrated into the modern economic system. The Muslims and the Christians lived side by side and connected with each other in the western Mediterranean. In this period the western region of the Mediterranean was not a divided region of the Islamic and the Christian cultures - like during the Spanish-Ottoman confrontation in the 16th century -, but it was an unified culture which related and contacted each other.

KEYWORDS Ottoman Maghreb, Mediterranean piracy/corsairing, renegat, peace and commercial treaties, Western European Powers

DOI 10.14232/belv.2017.2.4 https://doi.org/10.14232/belv.2017.2.4

Cikkre való hivatkozás / How to cite this article: Palotás Zsolt (2017): Kapcsolatok oszmán ÉszakAfrika és a nyugat-európai államok között (1605-1704). Belvedere Meridionale 29. évf. 2. sz. 66-84. pp.

ISSN 1419-0222 (print) ISSN 2064-5929 (online, pdf)

(Creative Commons) Nevezd meg! - Így add tovább! 4.0 (CC BY-SA 4.0)

(Creative Commons) Attribution-ShareAlike 4.0 International (CC BY-SA 4.0)

www.belvedere-meridionale.hu

${ }_{1}^{1}$ Jelen tanulmány a 2011. április 22-én az Euro-mediterrán világ - szomszédság és partnerség című budapesti konferencián elhangzott előadás szerkesztett, illetve bővített változata. Alulírtak részletesebb kifejtését lásd doktori értekezésünk vonatkozó fejezeteiben. РALOTÁs 2017. 


\section{Bevezetés}

A kora újkori Földközi-tenger, ezen belül is a Magreb-térség történetének vizsgálata nem tartozik a hazai történetírás által kiemelten kutatott területek közé. A nemzetközi kutatás ezzel szemben mindig is nagy érdeklődést mutatott a régió históriája iránt. A külföldi történészek vizsgálódásának homlokterében többek között a mediterrán kalózkodás, a különböző konfliktusok, államaik kereskedelme és azok diplomáciai kapcsolatai álltak a Magreb-államokkal, vagyis a Marokkói Királysággal, az Algíri, a Tuniszi és a Tripoliszi Kormányzósággal. ${ }^{2}$

Jelen tanulmány célja, hogy képet adjon a magyar olvasó számára a nyugati államok, Anglia, Hollandia és Franciaország kapcsolatairól az észak-afrikai kalózállamokkal, Algírral, Tunisszal és Tripolival az oszmán uralom időszakában. A dolgozat elsősorban a diplomáciai események és az egyes konfliktusok vizsgálata mentén ismerteti az államok közötti kapcsolatokat. A fejtegetés során kiemelt figyelmet szenteltünk a mediterrán kalózkodás sajátosságainak, résztvevőinek és következményeinek. A nyugati államok elsősorban a muszlim kalózkodás következtében kénytelenek voltak tárgyalásokat folytatni hajóik biztonsága érdekében a Magreb-államokkal.

A tanulmány elsősorban a 17. század eseményeire fókuszál, azonban bizonyos esetekben visszatekint a korábbi századra, emellett kitekintést is ad a muszlim kalózkodás 19. század eleji hanyatlásáról. A címben megjelölt két évszám egy-egy szerződés megkötésének dátumát jelöli. A 17. században először a francia monarchia kötött megállapodást a Magrebben, 1605-ben, Tunéziával. Kronológiai időhatárunk záró dátumát az 1704-es esztendő jelenti, mely szintén egy Tunisszal kötött szerződést jelöl, ebben az esetben a Holland Egyesült Tartományokkal.

Az 1605 és az 1705 közötti időszakban Anglia, Hollandia és Franciaország általában hasonlóan, időnként azonban teljesen különböző módon politizált a Magreb-államokkal. Kezdetben közös elem volt az Oszmán Birodalom támogatásának elnyerése kereskedelmi érdekeik védelmében. Amikor nyilvánvalóvá vált, hogy a Fényes Porta befolyása az észak-afrikai tartományokban többnyire csak névleges, akkor vették fel a nyugati-államok a közvetlen kapcsolatot ezekkel az államokkal.

\section{Historiográfia}

A kora újkori Mediterráneum, így a kalózkodás történetének kutatása elsősorban angol, francia, német és olasz nyelvü történelemtudományi munkákhoz köthető. ${ }^{3} \mathrm{Az}$ észak-afrikai kalózkodás történetével kapcsolatban elöször is meg kell említenünk Stanley Lane-Poole, The Barbary Corsairs $(1890)^{4}$ című munkáját. Lane-Poole a népszerüsítő irodalmakkal szemben döntően dokumentumokra és levéltári forrásokra támaszkodott a mediterrán kalózkodás históriájának bemutatása során. Számos koloniális történészhez hasonlóan, azonban igen negatívan ítélte meg a muszlimok szerepét a kalózkodásban. ${ }^{5}$

${ }^{2}$ A szakirodalomban és a forrásokban Algír, Tunisz és Tripoli egyaránt jelöli a politikai központokat, illetve az egyes kormányzóságok teljességét is. Az alábbiakban, amikor például Tuniszra utaltunk, azt általában az utóbbi értelemben tettük.

${ }^{3}$ Az alábbi historiográfiai összefoglalóban nem törekedtünk, nem is törekedhettünk a teljességre, hiszen a témában megjelent írások száma könyvtárnyi méretü. Az alábbi bibliográfákat, munkákat és a tanulmányban felhasznált írások irodalomjegyzékét ajánljuk a kora újkori Földközi-tenger és a kalózkodáshoz történetének tanulmányozásához: Blondy 2003.; Bryson 1979.; PenNell 1998.; RASOR 1979.

${ }^{4} \mathrm{Az}$ irodalom ismertetése során a föszövegben a monográfiák első kiadási évét és eredeti címét tüntettük fel. $\mathrm{Az}$ általunk ténylegesen használt, újra kiadott, illetve magyar fordításban megjelent munkák kiadási éveit a lábjegyzetben, illetve az irodalomjegyzékben közöltük.

${ }^{5}$ LANe-Poole 1890. 
A korai kutatásra jellemző volt, hogy elsősorban a nyugatiak nézőpontjából közelítettek az észak-afrikai kalózkérdéshez. Kijelenthető, hogy viszonylag kevés forrás maradt fenn a kalózok szemszögéből. A nyugati történészek munkáját emellett nagyban nehezítette az a tény, hogy azok a források, melyek fennmaradtak, elsősorban arab és oszmán-török nyelven íródtak. A kutatási irányokat ennek megfelelően bizonyos részkérdések vizsgálata jelentette, például a keresztény rabok életének és a konfliktusok eseménytörténetének ismertetése. Az amerikai kutatók például szinte teljesen feldolgozták a Tripoli elleni, 1801 és 1805 közötti háború történetét. Ilyen munka Gardner Weld Allen, Our Navy and the Barbary Corsairs (1905) című könyve is. ${ }^{6}$ Emellett Julian Stafford Corbett kiváló angol haditengerészeti történész, England in the Mediterranean (1904) címü munkájában az angol korona észak-afrikai jelenlétéről, elsősorban a marokkói Tanger városáról írt. ${ }^{7}$

A második világháborút követően a nyugati kutatók a keresztény forrásokon keresztül már megpróbálták árnyalni az eseményeket, és igyekeztek bemutatni az észak-afrikaiak nézőpontját is a kalózkérdésben. A korábban kialakult szemléletben hozott radikális változást Godfrey Fisher munkássága. Fisher 1957-ben megjelent, The Barbary Legend című munkája egyszer és mindenkorra eloszlatta a kalózkodással kapcsolatban kialakult sztereotípiát. Fisher monográfiája, mely nagyban támaszkodott a nyugati forrásokra, elsősorban diplomácia- és hadtörténetet mutatott be. A könyv egyik legfontosabb következtetése az, hogy a Földközi-tengeren nem csak muszlim, hanem keresztény kalózok is fosztogatták a kereskedelmi hajókat és a partokat. ${ }^{8}$

A Nyugat-centrikus megközelítéssel szemben Roger Coindreau francia történész a nyugati forrásokra támaszkodva már teljes egészében olyan monográfiát írt, mely az észak-afrikai államok szempontjából mutatta be a kalózokat. A Les Corsaires de Salé (1948) című munka a muszlim kalóz vállalkozások szervezését, a támadások rendszerét, a hajókat, illetve az abban résztvevő kapitányokat vizsgálta, elsősorban a marokkói Szalé kalóztevékenységének tükrében. ${ }^{9}$ Továbbá a Mediterráneum 16. századi történetéről átfogó képet adott Fernand Braudel, La Méditerranée et le monde méditerranéen a l'époque de Philippe II (1949) című alapmunkája. A magyar fordításban is megjelent monográfiából számos kérdés mellett a kalózkodás előtörténetéről is képet kapunk. ${ }^{10}$ Emellett a mediterrán kalózkodás történetének jelentős kutatóját, Salvatore Bonot emelhetjük ki, akinek munkássága minden tekintetben úttörő jelentőségű. Bono 1964-es monográfiája, I corsari barbareschi, mely az évek során több kiadásban és nyelven is megjelent átdolgozva, illetve kiegészítve szintén a kalózok szemszögéből közelített az eseményekhez. ${ }^{11}$

Az 1970-80-as években tovább folytatódott a Coindreau-hoz hasonló megközelítés alkalmazása. John Baptist Wolf, The Barbary Coast: Algiers under the Turks 1500-1830 (1979) és William Spencer Algiers in the Age of Corsairs (1976) címü munkája elsősorban oszmán forrásokra támaszkodva mutatta be Algír történetét. ${ }^{12}$ Továbbá Peter Earle angol történész kutatását említhetjük meg, mely jelentősen támaszkodott a Máltán található nagymennyiségü levéltári forrásra. Earle monográfiája, Corsairs of Malta and Barbary (1970) elsősorban ezeket a forrásokat használta fel. ${ }^{13} \mathrm{Az}$ angol kutató a máltai források mellett számos elsődleges és másodlagos szakirodalmat is figyelembe vett munkájának elkészítése során. Earle monográfiájában nem csak

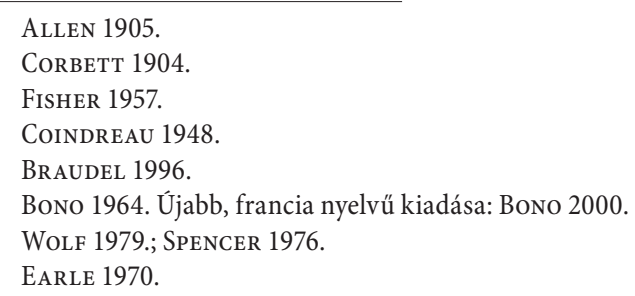


a muszlim kalózkodást mutatta be, hanem részletesen kitért a máltai Szent János Lovagrend kalóztevékenységére is a Földközi-tengeren.

Az 1980-as évek kutatásának további jellemző vonása volt, hogy a nyugati renegátok kalózkodásáról is igyekezett beszámolót adni. Christopher Lloyd, English Corsairs on the Barbary Coast (1981) címü munkája az angol renegátok fosztogató tevékenységét mutatta be Észak-Afrikában. ${ }^{14}$ A munkák emellett az Észak-Afrikába kinevezett konzulok naplóinak kiadásával foglalkoztak. Richard C. Pennell közölte például Thomas Baker, a Tripoliba kinevezett angol konzul (1677-1685) naplóját, Thomas Baker Piracy and Diplomacy in the Seventeenth-Century North Africa (1989) címü forráskiadványában. ${ }^{15}$ Pennell a munka bevezető tanulmányában elsősorban diplomáciatörténeti szempontból közelített Észak-Afrika, különösen Tripoli és a nyugati államok 17. századi történetéhez. A diplomáciai megközelítés jellemezte Alexander Hendkrik de Groot 1985-ben megjelent, Ottoman North Africa and the Dutch Republic in the Seventeenth and Eighteenth Centuries címü tanulmányát is. A holland kutató véleménye szerint a nyugati államok, például Anglia és Hollandia is fontosnak tartották kapcsolataik, elsősorban kereskedelmi kapcsolataik fenntartását Észak-Afrikával. ${ }^{16}$

A legújabb kutatásokra jellemző, hogy számos eddig nem igazán vizsgált kérdést vettek nagyító alá. Robert Charles Davis, Counting European Slaves on the Barbary Coast (2001) tanulmánya a keresztény rabok pontos számáról közölt hasznos információkat a barbár partokon. ${ }^{17}$ Továbbá a muszlim kalózkodás mellett egyre inkább elötérbe kerültek a keresztény kalózok is. A fentebb említett máltai Szent János Lovagrend kalózkodását számos kutató vizsgálta. Joseph Muscat, The Maltese Corso (1997) címü tanulmányából például az ispotályosok kalózkodásának szervezéséről, felépítéséről és tevékenységéről kapunk képet. ${ }^{18}$ Emellett Molly Greene, Catholic Pirates and Greek Merchants (2010) címü munkájában elsősorban a keleti keresztények, elsősorban a görögök szempontjából értékelte a máltai hajósok fosztogatásait a tengeren. ${ }^{19}$

A Mediterráneum 17. század végi politikatörténetéről átfogó képet adott Ekkehard Eickhoff német kutató, Venedig, Wien und die Osmanen: Umbruch in Südosteuropa, 1645-1700 (1970) című munkája. ${ }^{20} \mathrm{~A}$ fentebb említett Salvatore Bono legújabb könyve, a korábbi monográfiáinak kiegészítése, a Piraten und Korsaren im Mittelmeer (2009) szintén összefoglaló módon dolgozta fel a földközi-tengeri kalózkodás történetét. ${ }^{21}$ Továbbá kitűnő munka a kalózkodás végének bemutatásáról Daniel Panzac, Les corsaires barbaresques : la fin d’une épopée, 1800-1820 (1999) című könyve. Panzac munkájának egyik legnagyobb érdeme, hogy a politikatörténet mellett az észak-afrikai kalózok szemszögéből, azok kereskedelmi tevékenységén keresztül is bemutatta az eseményeket. ${ }^{22}$

14 LLOYD 1981.

15 Pennell 1989.

16 Groot 1985.

17 DAvis, 2001. Davis monográfiája 2003-ban jelent meg a keresztény rabszolgákkal kapcsolatban Észak-Afrikában. Davis 2003.

18 Muscat írását és számos egyéb tanulmányt a máltai lovagokról lásd Villain-Gandossi - DuRTESTE Busuttil 1997. A lovagrend történetéhez és kalózkodásához lásd Mallia-Milanes 1993.; Sire 1994.; Nicholson 2001.; CASSAR 1960. 140-156.; BoNo 1993. 388-397.

19 GreEne 2010.

20 EickHoFf 2010.

21 BONO 2009.

22 PANZAC 2005. 


\section{A Földközi-tenger keresztény és muszlim kalózai}

A 16. században az Oszmán Birodalom és észak-afrikai vazallus, adófizető államai háborúban álltak a spanyol Habsburgokkal és szövetségeseikkel a Földközi-tengeren. ${ }^{23}$ A nagyszabású tengeri hadmüveletek (1538. Préveza, 1535. Tunisz, 1541. Algír, 1560. Dzserba, 1565. Málta stb.), ${ }^{24}$ melyeket az oszmánok indítottak a spanyolokkal szemben és viszont, szinte teljesen megszüntek a lepantói csatát követően, mely a legnagyobb tengeri ütközet volt a felek között 1571. október 7-én. ${ }^{25}$ Fernand Braudel az eseményeket összegezve megállapította, hogy ezen tengeri csatát követő években a nagy háborút felváltotta a kalózkodás, melynek során kereskedelmi hajókat és az ellenséges partokat támadták mind a keresztény, mind a muszlim kalózok. ${ }^{26}$

A kalózkodás kérdésével kapcsolatban elsősorban a karib-tengeri kalózkodás kutatása öleli fel a legnagyobb szakirodalmat. ${ }^{27}$ Lényeges különbség van a kalózkodás karibi változata és az európai vizeken történő kalózkodás között. A Mediterráneumban egészen a 17. századig nem használatos a piraterie, tengeri banditizmus és a pirate, tengeri rabló szó. A 17. század elejéig a források course-ről, kalózkodásról/korzóról és corsaire-ről, kalózról/korzáróról számolnak be. A 17. századtól kezdve mindkét tevékenység megtalálható volt a Földközi-tengeren. Az elnevezések olyan hajóst takartak, aki föként fosztogatásból élt. A tengeri bandita és a corsaire közötti lényeges különbség azonban az volt, hogy az utóbbi tevékenysége megengedett hadviselés volt, melyre szabályos hadüzenet, kalózlevél, oltalomlevél adott felhatalmazást. A Földközi-tengeren minden hatalom elismerte a kalózkodást, mint a háború egyik megnyilvánulási formáját, a keresztények ugyanúgy fosztogattak a tengeren és a partokon, mint muszlim társaik. ${ }^{28}$

A legjelentősebb keresztény kalózok egyrészt a Szent János Lovagrend tagjai voltak. A lovagok levantei szálláshelyük, vagyis Rodosz 1522-es elvesztését követően kapták meg a Máltaiszigeteket (Málta, Gozo és Comino) és Tripolit hübérbirtokul Habsburg Károly német-római császártól (1530-1558) és spanyol uralkodótól (1519-1556) 1530-ban. ${ }^{29}$ A lovagrend kalózai meghatározott jogi keretek között tevékenykedtek a tengeren, melyet az 1605-ben Alof de Wignacourt nagymester (1601-1622) által kiadott statútum, illetve az úgynevezett Tribunale degli Armamenti testület szabályozott és ellenőrzött. ${ }^{30}$ Jelentős keresztény kalózok voltak továbbá a Szent István Lovagrend tagjai is, akik rendjét a toszkán nagyherceg, Cosimo de’ Medici firenzei fejedelem (1537-1569) hozta létre a 16. század közepén. ${ }^{31}$ Az egyházi lovagrendek mellett hatékonyan fosztogatták a hitetlenek hajóit továbbá a délszláv uszkokok, vagyis a törökök elöl menekülő szláv népesség egy csoportja, akik a Habsburg uralkodóktól kaptak engedélyt letelepedni Horvátországban és Szlavóniában. ${ }^{32}$ Ezek a kalózok a muszlim vitorlások mellett a

${ }^{23}$ A régebbi szakirodalomban általában az úgynevezett vazallus állam (vassal state) megjelölés olvasható, melyet a közelmúlt kutatásai egyre inkább az adófizető (tributary state) terminussal váltottak fel. Mindkét fogalom lényegében azt jelenti, hogy ameddig az adott terület rendszeresen fizette az adót a szultánoknak, addig azoktól védelmet kaptak, és bizonyos szintü függetlenséget élveztek. KARMAN-KunčEvić 2013.

${ }^{24}$ Crowley 2014.

25 A lepantói csatáról és annak hatásairól hatalmas szakirodalom áll rendelkezésünkre. Uo. 331-360.; ANDERSON 1952. 36-54.; Braudel 1996. 3:1155-1177.; Glete 2000. 104-106.; Guilmartin 1974. 221-252.; Hess 1972.; KONSTAM 2003.

${ }^{26}$ Braudel 1996. 2:915.

27 Pennell 1998. 61-79.

${ }^{28}$ Braudel 1996. 2:916-917.

29 Deed of Donation of the Maltese Islands 2011.

30 Cassar 1960. 142.; Bono 1993. 392.; Cavaliero 1959. 226.

${ }^{31}$ EICKHOFF 2010. 162-167.

32 Rothenberg 1961. 148. Az uszkokok tevékenységéhez lásd uo. 148-156.; Tenenti 1967. 3-15. 
velencei hajókat is megtámadtak, hasonlóan a nyugati-európai államok hajósaihoz, akik közül a velencei források tanúsága szerint az angol kalózok voltak a legkegyetlenebbek. ${ }^{33}$ A Serenissima, mely érdekelt volt az Oszmán Birodalommal való kereskedelmi kapcsolatok fenntartásában igen negatívan vélekedett a keresztény kalózkodásról. A fentebb említett Szent János Lovagrend tagjait például a velencei szenátus egyszerűen csak „kereszttel parádézó kalózoknak” tartotta. ${ }^{34}$ (1. ÁBRA)

A nyugati források mindezek mellett leginkább a hitetlenek rablótevékenységét tekintette

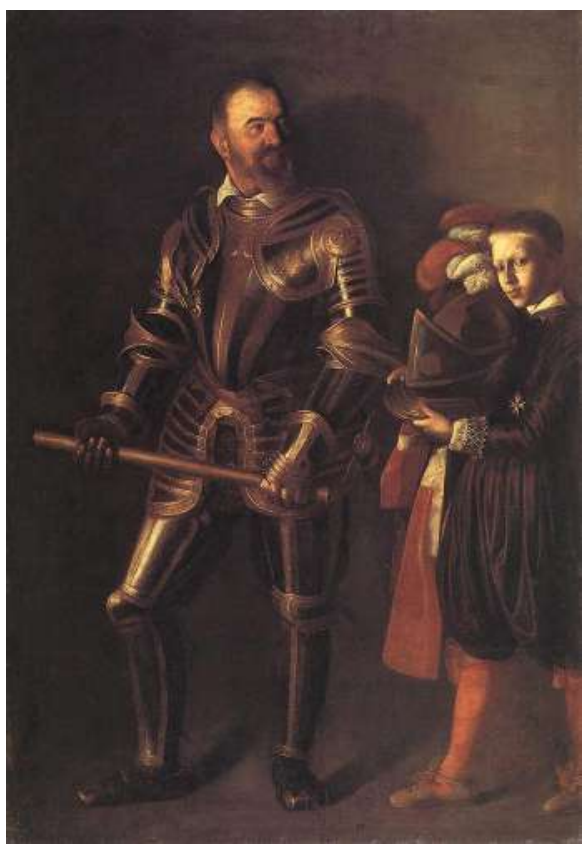

1. ÁBRA Michelangelo Merisi da Caravaggio (1571-1610) portréja Alof de Wignacourt nagymesterröl és annak apródjáról. (NICHOLSON 2001. Plate VI.; https://commons.wikimedia.org/ wiki/File:Alof_Louvre.jpg, hozzáférés: 2015.07.15.) a keresztény világ legnagyobb csapásának, melynek központjai Észak-Afrikában voltak. ${ }^{35}$ Egyrészt jelentős kalózkikötők voltak a Marokkói Királyságban: például a fentebb említett Szalé városa. Marokkó sikeresen meg tudta örizni függetlenségét mind a spanyolok, mind az oszmánokkal szemben. Észak-Afrika többi része ezzel szemben a két hatalom hadszíntere volt a 16 . században, mely régiót végül az oszmánok csatolták birodalmukhoz.

Az oszmán uralom alatt álló területek alattvalói, marokkói társaikhoz hasonlóan folytattak kalóz tevékenységet. Észak-Afrikában három úgynevezett oszmán kalózállamról beszélhetünk, melyek keletről nyugat felé haladva a következőek voltak: Tripoli, Tunisz és Algír. Az Oszmán Birodalom először Algírt (1529), ezt követően Tripolit (1551), majd Tuniszt (1574) foglalta el a keresztényektől, és hozta létre észak-afrikai tartományait, melyek elnevezése kormányzóság (regency, régence) a nyugati forrásokban és a modern szakirodalomban. A Fényes Porta kezdetben szandzsákokat (pasalik) szervezett a Magrebben, melyek élén a három évre kinevezett pasák álltak. Később az oszmánok külön-külön igazgatták az egyes tartományokat, melyek időnként önálló diplomáciát is folytattak. Ennek magyarázata egyrészről az, hogy a törökök ezeken a területeken, mivel Isztambul messze volt, sohasem tudták teljesen kiterjeszteni hatalmukat. A városok emellett kitüntetett szerepben voltak a birodalmon belül, hiszen az oszmán flotta legütőképesebb alakulatait adták. ${ }^{36}$

A 17. században a muszlim kalózkodása, mely első számú forrása volt a janicsárok és kalózkapitányok, az úgynevezett raiszok (arab: ra’is) ellátásának és gazdagságának szükséges tevékenysége volt az észak-afrikai barbár városoknak. Ennek megfelelően a kalózok a kereskedelmi hajókat vagy a partokat támadták a zsákmány reményében. Braudel kitűnően fogalmazta

33 A Velencei Köztársaság és az angol kalózok kapcsolatához lásd uo. 56-86.

34 Uo. 39; Mallia-Milanes 1992. 15-35.

35 Eickhoff 2010. 167-171.; Playfair 1884.

36 Az oszmán flotta legkiválóbb kapudán pasája, vagyis föparancsnoka a Mütiléné-szigetén (Leszbosz) született Hajreddin Barbarossa (arabul: Khair ad-Din) volt az, aki komoly szerepet vállalt többek között az oszmán terjeszkedés elősegítésében a Magrebben. RANG-Denis 1837. Az oszmán flotta észak-afrikai föparancsnokaihoz lásd LANE-Poole 1890. 31-140.; NAYLOR 2009. 117-120. 
meg munkájában, hogy a kalózkodás és a kereskedelem szorosan összefüggtek egymással a kora újkori Földközi-tengeren. ${ }^{37} \mathrm{~A}$ 17. századtól kezdve például egyre sűrűbben érte támadás az angol, francia és holland hajókat. Továbbá a barbár kalózok már előszeretettel hajóztak és fosztogattak a Földközi-tengeren kívül is: muszlim hajók jelentek meg például Anglia partjainál, a Baltikumban és Izlandnál is. ${ }^{38} \mathrm{Az}$ igazi zsákmányt elsősorban a rabszolgák jelentették, akik között egyaránt voltak muszlimok és keresztények is. Egyrészt az elfogottak tették ki a muszlim gályák evezőseinek jelentős részét. Másrészt sajátos iparág alakult ki a foglyok kiváltására. Igen jövedelmező volt például gazdag emberek foglyul ejtése, hiszen a kalózok magas váltságdíjat követelték egy-egy gazdag rab szabadon bocsátásáért. ${ }^{39}$ A nyugati államok a foglyok kiváltására és kereskedelmi kapcsolataik kiépítésére fokozatosan tárgyalásokba kezdtek az észak-afrikai városokkal.

\section{Keresztény renegátok Észak-Afrikában}

A 17. század elején több, a korábbi háborúkban kimerült nyugati állam kötött békeszerződést egymással. Ilyen szerződések voltak a spanyolok megegyezései Franciaországgal 1598-ban, Angliával 1604-ben és Hollandiával 1609-ben. Csupán a spanyolok és elsősorban a velenceiek ellenségeskedtek továbbra is az oszmánokkal (lásd például a Kandia, vagyis a Kréta elleni oszmán hadjáratot 1645 és 1669 között) a Mediterráneumban. Emellett a spanyolokkal kötött békéknek köszönhetően a francia, az angol és föleg a holland kereskedelem virágzott a Földközi-tengeren. ${ }^{40}$

Széles körben közismert, hogy az észak-afrikaiak mellett a nyugati államok is alkalmaztak kalózokat az újkorban. Alexander de Groot holland kutató állítása szerint például 1606 és 1609 között a holland Staten Generaal (Össztartományi Gyűlés) körülbelül 130 embernek adott ki olyan iratot, mely felhatalmazta tulajdonosát a spanyol hajók elleni kalózkodásra. ${ }^{41} \mathrm{Az}$ angol kalózok is rendszeresen rajta ütöttek az Újvilágból érkezö, arannyal és ezüsttel gazdagon megrakott spanyol hajókon. ${ }^{42}$ Közös elem volt, hogy mind a holland, mind az angol kalózkodás célja a spanyol kereskedelem zaklatása volt. Mivel a spanyol háború lezárásával megszünt jövedelmező tevékenysége, számos angol és holland kalóz indult az oszmánok észak-afrikai adófizetői államaiba, és tért át ott az iszlám hitre, vagyis lett renegát, hogy ott folytassa jövedelmező tevékenységét. ${ }^{43}$ Igen beszédes ebben a vonatkozásban a muszlim flották kapitányainak származása. 1626-ban például az algíri flotta 55 kapitánya eredetileg holland volt. ${ }^{44}$ Németalföldi származású volt Simon Simonsen, alias Danser és Kör Murád raisz, vagyis Jan Jansoon is. Egyrészt Danser volt feltehetően az, aki először ismertette meg a muszlim kalózokat a tengeri hajózás modern módszereivel. Másrészt a Murád által vezetett kalózhajók jutottak el első alkalommal Izlandra 1627-ben. ${ }^{45}$

\footnotetext{
37 BRAUdel 1996 2:934.

38 Az Izland elleni kalózvállalkozáshoz lásd LEWIs 1973.

39 BRAUdel 1996. 2:922., 938-940.

40 A 17. század elején évente körülbelül 1200 holland kereskedelmi hajó haladt át a Gibraltári-szoroson, és kereskedett a Földközi tengeren. Groот 1985. 133.

41 Uo. 131.

42 Közismert példa erre Sir Francis Drake (1540 körül -1596) kalózkodása a spanyol flotta ellen. Drake és az angol kalózok tevékenységéhez Lásd többek között: AndRews 1964.; CoRBeTt 1899.; RyAn 1999. $29-45$.

43 Groot 1985. 132.; KrIEKeN 1993.

44 Uo. 132. idézi HeEringa 1910. 1917. 1: 976-977.

45 Groot 1985. 132.
} 
Az északról jött tengerészeknek, ahogyan azt fentebb említettük jelentős szerepük volt a vitorlás hajók hadviselésének elterjesztésében a Földközi-tengeren. A hajók többsége azonban még mindig evezővel ellátott gálya volt, mely nagymértékben az emberi hajtóerőre és az időjárásra volt utalva. ${ }^{46} \mathrm{Az}$ északi hajótípus ezzel szemben vitorláinak köszönhetően rengeteg időt tudott a tengeren tölteni. Emellett a vitorláshajók sok ágyút tudtak hordozni fedélzetükön, így a tüzerejük is megnövekedett.

Összefoglalva kijelenthető, hogy a több ezer európai renegáttal Tunisz, Tripoli és föleg Algír a 17. század első felében a kalózok bázisa volt. Továbbá a nyugati renegátok tevékenysége a modernizáció és nyugatizálódás korai megjelenési formáját jelentette az iszlám világban. A keresztény és a muszlim lakosság és tengeri kultúra ugyanis keveredett és hatással is volt egymásra Észak-Afrikában. ${ }^{\bowtie 47}$

\section{Szerződések és konfliktusok a 17. század első felében}

A 17. század első felében a kalózok eredményességét elősegítette az európai államok pillanatnyi gyengesége. A katonai szempontból gyenge nyugati államok elsősorban diplomáciai kapcsolatokat építettek ki ekkor az észak-afrikai államokkal. A nyugati államok első lépésben Isztambulhoz közeledtek kereskedelmi érdekeik biztosítása érdekében. A kapcsolatfelvétel eredményeképpen az oszmán szultánok kapitulációkat, úgynevezett ahdnamékat kötöttek a keresztény államokkal. A Fényes Porta először a franciákkal (1535), ezt követően az angolokkal (1579/1580), majd a hollandokkal (1612) kötött kereskedelmi szerződést. ${ }^{48}$ Az oszmánokkal való kapcsolat emellett segített abban, hogy a nyugatiak elnyerjék az észak-afrikai tartományok vezetőinek együttmüködését is. Az adófizetőknek a kapitulációk értelmében biztosítaniuk kellett a hajók sérthetetlenségét, haza kellett engedniük a foglyul ejtett embereket és biztosítaniuk kellett azt, hogy a szerződő felek kereskedelmét nem akadályozzák. A kapcsolat azonban, ahogyan azt korábban megfogalmaztuk az oszmán észak-afrikai tartományok és a Fényes Porta között igen laza volt. Algír, Tunisz és Tripoli széles körủ autonómiát élvezett a 17. században. Az egyes pasák és dejek többnyire meglehetősen lazán értelmezték a kormányzat utasításait, és a kapitulációkban foglaltakat nem mindig tartották be. (2. ÁBRA)

A 17. század első felében a muszlim korzárók igen aktívak voltak a tengeren. Az 1613-tól 1622-ig tartó időszakban például az algíri kalózok 963 hajót fogtak el és vittek a tartományi központba, Algírba. A megtámadott hajókból 447 holland, 253 pedig francia volt. ${ }^{49} \mathrm{~A}$ francia politikai vezetés ütőképes flotta hiányában nem tehetett mást, minthogy tárgyalásos úton megegyezik az algíri dívánnal, vagyis a legfelsőbb tanáccsal. A tárgyalások eredményeképpen Franciaország volt az első európai állam, mely kapcsolatokat épített ki a Magrebbel a 17. században. A siker alapja a Fényes Porta közbenjárása volt. A franciák először Tunisszal 1605-ben, majd Algírral 1628-ban kötöttek szerződést. ${ }^{50}$ Az angolok is, hasonlóan a franciákhoz keresték

\footnotetext{
46 A barbár városok flottáinak számához és az alkalmazott hajótípusokhoz lásd EARLE 1970. 45-50.; PANZAC 2005. 45-72.

47 Groot 1985. 132.

48 Boogert 2005.; PAnZAC 2005. 27. Braudel monográfiájában az Anglia és az Oszmán Birodalom között létrejött megállapodás dátumát 1580 júniusára tette. BrAUDEL 1996. 2:670.

49 PANZAC 2005. 27. idézi Wolf 1979. 190. A különböző időszakokban elfogott hajók és a megtámadott szárazföldi települések számához lásd DAVIs 2001. 87-124.

50 CARD 1906. 143-145., 45-49., 20-22.
} 


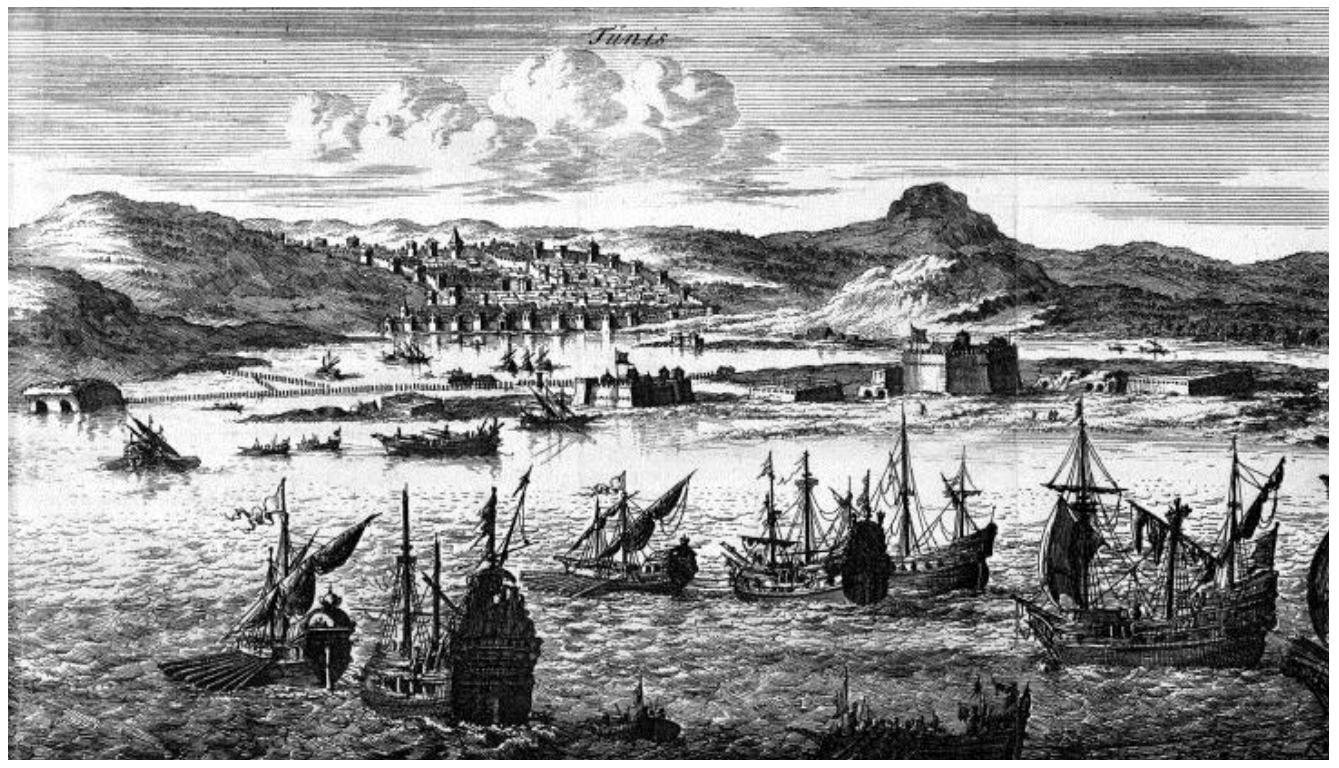

2. ÁBRA * Tuniszés annak kikötővárosa, azaz La Goletta 17. században. (DAN 1684a. 164. oldalt követöen;

DAN 1684b)

a tárgyalásos megoldás lehetőségét, és követték azok módszereit. Ennek megfelelően az angol korona 1622-ben tárgyalt Isztambulban az első, Algírral kötendő békeszerződésről. ${ }^{51}$

A hollandok, akik élen jártak a tengeri kereskedelemben a 17. században, szintén törekedtek arra, hogy megegyezésre jussanak a barbár kalózokkal. 1617-ben a németalföldi megbízott bizonyos Cornelis Haga (1578-1654), aki az első holland követ volt az Oszmán Birodalomban megszervezett egy hármas találkozót a nagyvezírrel és az algíri pasával Isztambulban 1612-ben. A pasa megígérte a korábbi kapitulációkban foglaltaknak, különösen azoknak a cikkelyeknek a betartását, melyek a kereskedelem és a hajózás szabadságára, illetve a keresztény rabszolgák szabadon bocsátására vonatkoztak. ${ }^{52}$ A hollandok ezt követően, 1622-ben kötötték meg a szerződést (sulhame) Algírral és Tunisszal. Algír a szerződés értelmében többek között elfogadta azt, hogy a kalózok nem kutathatnak át holland hajót ellenséges árut keresve. ${ }^{53}$

A különbözö szerződések szövegét megvizsgálva arra a következtetésre juthatunk, hogy kétoldalú kapcsolat jellemezte a szerződö feleket. Ekkor a nyugati és az észak-afrikai államok egyenlö tárgyaló partnerek voltak, hiszen a szerződésekben mindkét fél igényei és céljai is megtalálhatóak. Itt láthatjuk a kezdetét annak a speciális kapcsolatnak, mely a nyugati államokat és a kormányzóságokat jellemezte a 17-18. században.

A holland szerződés pontjait azonban a kalózok nem tartották be. A hollandok katonai erőt és diplomáciai megoldást egyaránt alkalmaztak, hogy a szerződésben foglaltaknak érvényt szerezzenek. Első lépésben egy holland hajóraj indult Algírba és Tuniszba 1624-ben. A flotta parancsnoka, Hendrikszoon „Mooy” Lambert (1550-1625) követelte a holland rabok szabadon bocsátását, továbbá azt, hogy kössenek új szerződést, melyet a feleknek tiszteletben kell tartani-

\footnotetext{
51 PANZAC 2005. 28.

52 Groot 1985. 135.; PANZAC 2005. 29.

53 Groot 1985. 136.
} 
uk. A holland flotta jelenlétének köszönhetően a megegyezés létrejött, és a béke megállapodást Algír és Tunisz vezetői is aláírták az 1626-os év folyamán. ${ }^{54}$ Az 1617-1626-os események kapcsán világos, hogy ettől kezdve az európai tárgyaló felek már nem csak diplomaták, hanem egyben admirálisok is voltak. A későbbiekben az angolok, franciák és a hollandok részéről a flotta küldése erődemonstráció volt, mely elősegítette a szerződések megkötését az észak-afrikaiakkal. Az események tanúságaként megállapítható, hogy a nyugatiak ettől kezdve a katonai erő alkalmazását és a diplomácia adta eszközöket párhuzamosan alkalmazták a Magreb-államokkal való kapcsolataik során.

Az 1626-ban megkötött szerződés mintául szolgált számos későbbi holland megegyezéshez. A szerződésben megengedték az észak-afrikai hajóknak azt, hogy németalföldi kikötőkbe menjenek, és hogy ott kereskedhessenek. A holland hajók és kereskedők szintén szabadon kereskedhettek Algírral. A szerződés továbbá lehetővé tette a holland alattvalók érdekeit képviselő konzul kinevezését Algír városába. Az algíri korzáróknak a szerződés értelmében továbbá megengedték, hogy átszálljanak a holland hajókra, és abban az esetben, ha kiderült, hogy a hajó Algír ellenségéhez tartozó árut, illetve utasokat szállított, akkor azokat lefoglalhatták. A legfontosabb kérdés a rabokkal kapcsolatban alakult ki. A holland foglyokat váltságdíjfizetésé, vagy a hollandok által elfogott észak-afrikai muszlimok szabadon bocsátása fejében elengedték. Fontos továbbá megjegyezni, hogy a foglyok kiváltásával elsősorban a különböző szabadító rendek, például a Trinitáriusok, továbbá a zsidó kereskedők foglalkoztak Algírban, Livornóban és a holland városokban. ${ }^{55}$ (3. ÁBRA)

A 16-17. században az észak-afrikaiaknak nem, vagy csak kisméretü volt a kereskedelmi flottájuk, így a tengeren folytatott árucsere az európai vállalkozók és tengerészek kezében maradt. ${ }^{56} \mathrm{Az}$ nyugat-európaiak elsősorban a helyi áruk iránt mutattak nagy érdeklődést (például búza, gyapjú és olaj), amiért cserébe saját áruikat ajánlották fel. A helyi vezetőréteg elsősorban úgynevezett „stratégiai” termékeket követelt, melyeket nem lehetett szállítani a Magrebbe. Ilyen stratégiai áru volt a lőpor, az ágyúgolyó, a kötél, illetve a vitorlavászon. ${ }^{57}$

A 17. század közepén a különböző európai konfliktusok, elsősorban a 30 éves háború következtében a nyugati hatalmak kapcsolatai az észak-afrikai államokkal másodlagosak lettek. A korzárók tevékenységükben nem voltak korlátozva, melyre jó példa, hogy az 1580-1680 közötti időszakban, átlagban körülbelül 27000 keresztény rabszolga tartózkodott Algírban. ${ }^{58}$ A rabok elsősorban spanyolok, itáliaiak, emellett franciák, hollandok, angolok, németek, görögök, lengyelek, szlávok, oroszok és magyarok voltak. ${ }^{59}$

A vesztfáliai béke 1648-as megkötése sem tette lehetővé az európai államoknak azt, hogy rögtön helyreállítsák korábbi kapcsolataikat az észak-afrikai kormányzóságokkal. Az 1658-1668 közötti években sikerült csak újból megerősíteni az 1620-as években kötött szerződéseket. Először is Hollandia kapcsolatai értékelödtek fel, és lettek egyre fontosabbak a kormányzóságokkal az angol-holland háborúk időszakában (1652-1674). 1662-ben például a holland nemzeti hős, Michiel Adriaenszoon de Ruyter (1607-1676) admirális hajózott Algírba és Tuniszba, hogy tárgyaljon a béke megújításáról. Egyrészt a szerződés értelmében az algíri és a holland kalózok

54 PANZAC 2005. 29.

55 Groot 1985. 138-139.

56 A Tuniszi Kormányzóság 17. századi kereskedelméről kitűnő monográfiát írt Sadok Boubaker tunéziai kutató 1987-ban. BOUBAKer 1987.

57 CHÉRIF 1999. 249-251.

58 Davies 2001. 108. Pierre Dan (?-1649), francia szabadítórendi szerzetes az Észak-Afrikában lévő keresztény rabszolgák számát egy millióban határozta meg. DAN 1646. 319.; DAN 1684a. 309.

59 Uo. 320 


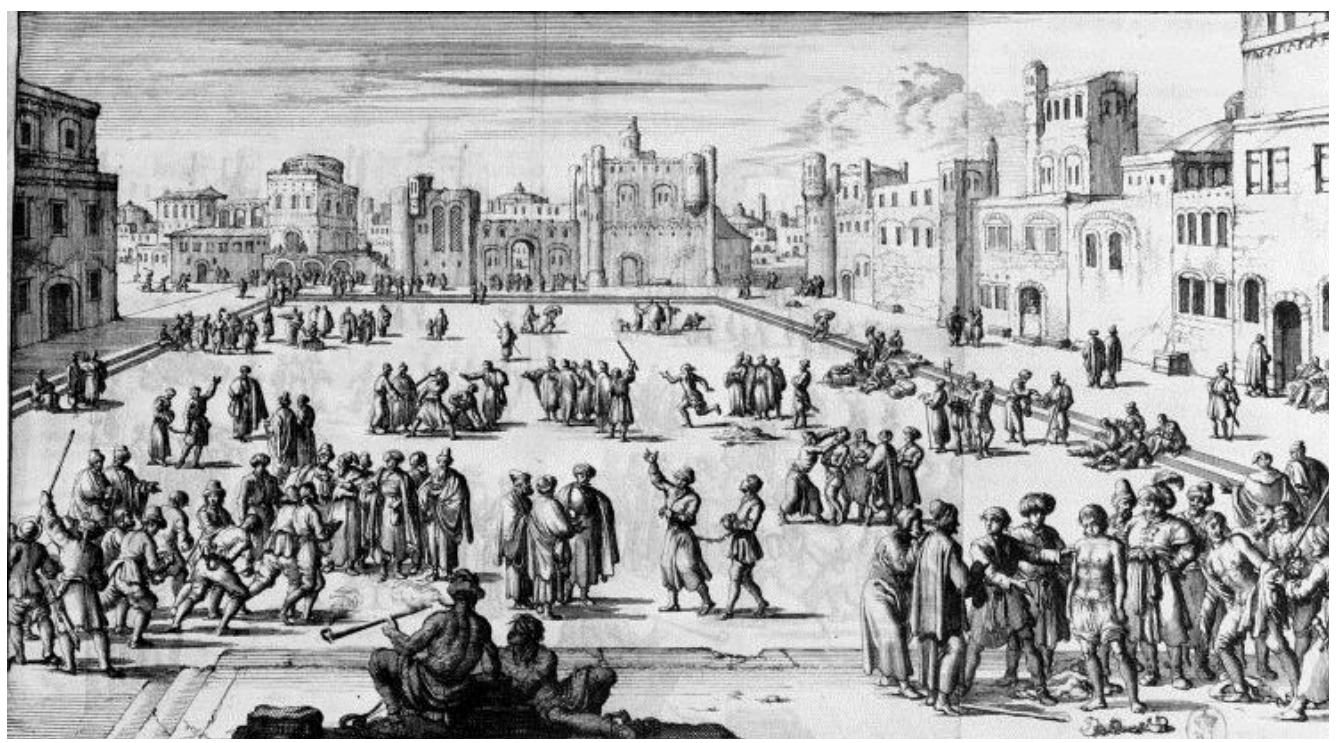

3. ÁBRA Keresztény rabszolgapiac Algírban. (DAN 1684a. 384. oldalt követöen; DAN 1684b)

nem támadhatták meg egymás kereskedőit. Másrészt a szerződésben megengedték a holland hajók átkutatását. Továbbá a holland foglyokat váltságdíj fizetésének fejében szabadon bocsátották. Ezen felül Algírral mindenki szabadon kereskedhetett, és a kereskedelmi termékekre normál adót vetettek ki. A szerződés értelmében azok a holland hajók, melyek idegen lobogó alatt hajóztak lefoglalhatóak voltak. A megállapodás végül szabályozta a mindennapi együttlét kereteit is Algírban. Egyrészt a hollandok és a muszlimok vitás ügyei az algíri díván hatáskörébe tartoztak. Másrészt a holland alattvalók ügyeiben a konzul járt el. ${ }^{60}$

A Holland Egyesült Tartományok elsőszámú tengeri riválisa, azaz Anglia volt az első európai hatalom, mely kapcsolatokat épített ki Tripolival 1658-ban. ${ }^{61} \mathrm{Az}$ angolok emellett helyreállították a békés viszonyt Algírral is 1660-ban. Az angol korona az új szerződéseket az észak-afrikai városokkal 1662-ben kötötte meg. ${ }^{62}$ Végezetül Franciaország a hollandokhoz és az angolokhoz hasonló szerződéseket írta alá Tunisszal és Algírral 1665-ben és 1666-ban. ${ }^{63}$

A szerződések ellenére az európai államok és az észak-afrikai oszmán adófizető államok közötti kapcsolat zsákutcába jutott. A szerződéseket sem a nyugatiak, sem az észak-afrikaiak nem tartották mindig tiszteletben. Az európaiak megelégelték azt, hogy hajóikat az észak-afrikai kalózok elfogják, továbbá azt, hogy a keresztény foglyok kiváltása is nagyon nehézkesen ment.

\section{Nyugat-európai „diplomata admirálisok” a Magrebben 17. század végén}

Az 1670-es évek elején a katonai- és politikai légkör merőben más volt, mint a korábbi időszakban. Az európai flották ugyanis sokkal erősebbek voltak, mint az 1620-1630-as években. Nem csupán a hajók száma növekedett meg, hanem számos hajó 80, 90 és 100 ágyút is hordo-

\footnotetext{
60 Groot 1985. 139.

61 Pennell 1989. 19.

62 Chalmers 1790. 2:361-365., 391-394., 407-411.

${ }^{63}$ CARD 1906. 116-123., 32-36.
} 
zott a fedélzetén. A nyugatiak flottái így tűzerőben és a taktikai manőverek alkalmazásában is nagymértékben felülmúlták a korzárók flottáit. ${ }^{64}$

Elöször a hollandok, akik három háborút vívtak az angolokkal, emellett a francia monarchiával is konfliktusba kerültek (1672-1678), voltak készek megegyezni a kalózokkal. 1679-ben Thomas Hees (1634-1692) holland követ volt az, aki új szerződést kötött a Holland Köztársaság nevében Algírral. ${ }^{65}$ A felek a korábbi szerződések megerősítése mellett megegyeztek számos kiegészítő cikkelyben is. Új elem volt, hogy a holland kereskedőket, legyenek azok keresztények vagy zsidók, a szerződés értelmében hasonló jogok illették meg Algírban. ${ }^{66}$ Továbbá 1683 júniusában Tripoli vezetői is megegyeztek abban, hogy az algíri szerződéshez hasonló békét kötnek a hollandokkal. Emellett Hees biztosította a dejt, hogy lőport, kötelet, ágyúgolyót és hajóárbocot is adnak Tripolinak. Az ilyen felajánlások megszokott részét képezték a tárgyalásoknak. Végezetül a holland követ Zacharias Cousartot nevezte ki konzulnak Tripoliba (hivatalban 1683-1693), aki így az első holland konzul lett a városban. ${ }^{67}$

A hollandoktól eltérően Anglia felhagyott a diplomáciai gyakorlattal, és a katonai erő alkalmazását választotta megoldásként hajói védelmére. 1670-ben például egy angol flotta hajózott Algírba, hogy érvényt szerezzen a korona akaratának. Az angol flotta, miután kiegészült egy holland egységgel, súlyos csapást mért a kalózokra. A katonai kudarc következtében Algírban felkelés robbant ki, melynek során az egyik kalózkapitány felvette a dej címet, és hajlott az angolokkal való megegyezésre. A szerződést végül 1673-ban kötötték meg az angolok és az algíriaiak. Tripoli esetében hasonló események játszódtak le, mint Algírban. 1675-ben ugyanis az angolok követelték, hogy a tripoliszi kalózok adják vissza a korábban elfogott angol hajókat. Az elutasító választ követően John Narborough (1640-1688) admirális blokád alá vett a várost, és elpusztította a tripoliszi flotta egy részét. Az új megegyezést 1676 márciusában kötötték meg, melynek értelmében a kalózok visszaadták az elfogott hajókat. Végezetül 1686-ban újból angol flotta érkezett Algírhoz és Tuniszhoz azért, hogy a korábban kötött egyezményt II. Jakab angol uralkodó (1685-1688) nevében megújítsák. ${ }^{68}$

Az 1680-as évek elején, XIV. Lajos uralkodásának időszakában (1643-1715) Franciaország hatalmának csúcsán állt. A franciák Jean-Baptiste Colbert (1619-1683) gazdaságpolitikus tevékenységének köszönhetően ekkor kezdték meg kereskedelmük kiterjesztését a Levantében. ${ }^{69}$ Az első lépést mégis Algír tette meg, és az angolokkal, illetve a hollandokkal való pillanatnyi jó viszony birtokában hadat üzent Franciaországnak 1862-ben. Abraham Duquesne (1610-1688) admirális 1682. július 29-én érkezett meg a francia flotta élén az algíri vizekre. A katonai cél többet már nem a hajók vagy a parti erődítmények támadása, hanem maga a város bombázása volt. A bombázás során több száz épület semmisült meg, azonban a flotta ennél többet nem tudott elérni. A következő évben a franciák így újból megtámadták a várost. A francia flotta hadműveletének az lett az eredménye, hogy az algíri díván szabadon engedett 500 francia rabot, és tárgyalásokat kért. Ekkor azonban már késő volt, hiszen Duquesne a katonai fölény birtokában a tárgyalások megkezdését elutasította. Ekkor Algírban egy Huszein, más néven Mezzomorto (törökül:

${ }^{64}$ A tengeri hadviselésben végbement változásokhoz a 17. században, az angol-holland háborúk időszakában lásd Palotás 2011.

65 Thomas Hees naplóját, melyben számos utalás van az Algírral folytatott tárgyalásara lásd BoUSQUETBousquet-Mirandolle 1957. 85-128.

66 Groot 1985. 140-142.

67 Uo. 143.

68 PANZaC 2005. 32-33.

69 Masson 1897. 


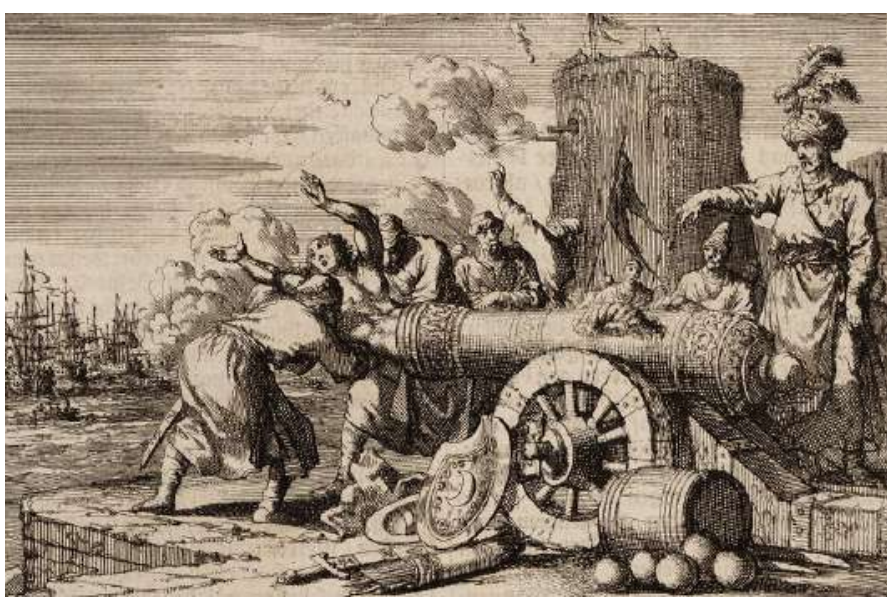

4. ÁBRA Jean Le Vacherfrancia konzul kivégzése 1683-ban (LUYKEN 1698)

Mezomorta Hüseyin) nevezetű kalózkapitány átvette a hatalmat, és számos franciát, köztük Jean Le Vachert (1619-1683) konzult is kivégeztetett. ${ }^{70}$ A tárgyalás ekkor holtpontra jutott, és a konfliktus csak a következő évben oldódott meg. 1684-ben Anne Hilarion de Cotentin (1642-1701) Tourville grófja és a francia flotta egyik legkiválóbb admirális, illetve a közvetítőként hozzá csatlakozott szultáni követ tárgyalt az algíriakkal. A tanácskozások eredményeképpen a felek végül aláírták a békeszerződést. ${ }^{71}$ (4. ÁBRA)

1687-ben Algír megszegte a korábbi szerződések pontjait, és ismét hadat üzent a francia monarchiának. 1688 tavaszán újból francia flotta hajózott Észak-Afrikába, mely ismételten bombázta a várost. A flotta vezetőjét, Jean II d’Estrées (1624-1707) admirálist azonban visszahívták Franciaországba. ${ }^{72} 1689$ áprilisában végül egy francia delegáció érkezett Algírba, hogy aláírjanak egy új szerződést. ${ }^{73} \mathrm{~A}$ franciák emellett négy mozsárágyút, 9000 bombát és egy vezető tüzértisztet küldtek az algériaiaknak, melyet azok alkalmazni tudtak Orán ostrománál. ${ }^{74}$

A francia politika Tripoli esetében hasonló megfontolások mentén körvonalazódott, mint Algír esetében. Egyrészt a franciák békeszerződést kötöttek a várossal 1681-ben. ${ }^{75}$ Másrészt két évvel később, 1683-ban Duquesne bombázta a várost, majd a békét 1685-ben kötötték meg újból. ${ }^{76}$ Végül 1692-ben Tripoli felújította az ellenségeskedést, melynek következtében a franciák 1693ban ismét lőtték a várost. A megegyezést, mely az 1692-es pontokat újította meg ugyanabban az évben fogadták el. ${ }^{77}$

70 Eeghen 1905. 1:369.; Eickhoff 2010. 323-324.; PAnZac 2005. 33-34.

71 Uo. 34.; CARD 1906. 45-52.

72 A francia korona a nemzetközi események hatására hívta vissza admirálisát a Földközi-tengerröl. 1688-ban ugyanis az angliai forradalom megfosztotta trónjától a XIV. Lajos által támogatott II. Jakabot. A tengeri háború Anglia és Franciaország között elkerülhetetlennek tünt.

73 CARD 1906. 52-60.

74 1508-tól kezdve a spanyolok tartották ellenőrzésük alatt Oránt. Az Oszmán Birodalom több alkalommal (például 1556-ban és 1563-ban) sikertelenül ostromolta a várost. Orán a spanyol korona hídfőállása volt az oszmánok észak-afrikai tartományában egészen 1708-ig, amikor is az algíriaiak elfoglalták a várost. 1732-ben a spanyolok visszafoglalták a területet, majd végül újra a törökök kezére került 1792-ben. Az Orán városáért folytatott harchoz a 16. században lásd ABUN-NASR 1971. 167-173.

75 CARD 1906. 243-244.

76 Uo. 244-253.

77 Uo. 253-262.; PANZAC 2005. 35. 


\section{A muszlim kalózkodás újbóli virágzása és alkonya a 18-19. század fordulóján}

Az 1689-1714-es időszak a francia és más európai hatalmak nagy összecsapásainak periódusa volt. ${ }^{78}$ Ez többek között azt jelentette, hogy ütőképes európai flották jelentek meg a tengereken, így a Mediterráneumban is, aminek következtében a kalózkodás kockázatos vállalkozás lett. A muszlim városok ennek megfelelően a szárazföldön kezdtek el terjeszkedni. Algír például háborút kezdett Tunisz ellen, mely a kormányzóság 1704-es megszállásához vezetett. Továbbá 1708-ban az algíriaiak sikeresen elfoglalták a spanyoloktól Oránt is. Összefoglalva kijelenthető, hogy a szárazföldi háborúk elfordították Algír katonai figyelmét a tengerről, emellett a kormányzóságok megkezdték integrálódásukat a tengeri kereskedelembe is.

A 18. században a tengeri konfliktusok ritkák voltak és soha nem jutottak el arra a szintre, mint a megelőző évtizedekben. Mindezek mellett a nyugati államok flottái ezen időszakban a korábbiakhoz hasonlóan elengedhetetlen szerepet játszottak a tárgyalások során. A század elején Hollandia ismét felvette a kapcsolatot Algírral, Tunisszal és Tripolival. A holland diplomaták 1703 és 1704 között három szerződést is kötöttek Észak-Afrikában. Az algíri 1704-es szerződés egyedülálló dokumentum, mivel a megegyezés magrebi arab nyelven íródott. ${ }^{79}$ A szerződések és a ratifikációk aláírását a hadihajókkal biztosított ajándékok küldése követte, ahogyan az már megszokott gyakorlatnak számított.

A 18. század végén és a 19. század elején a kalózkodás még egyszer virágkorát élte. Ennek a virágzásnak az oka többek között a francia forradalmi háborúk (1789-1802) és a napóleoni háborúk (1803-1815) voltak. A nyugati államok a kontinensen zajló háborúskodással voltak lekötve, így a Földközi-tenger újra szabad prédát jelentett a kalózok fosztogatásainak. A kalózok merészségét mi sem mutatja jobban, minthogy az 1783-ban függetlenedett Amerikai Egyesült Államokkal is konfliktusba kerültek. A fiatal köztársaság az angolokhoz és a hollandokhoz hasonlóan kezdetben szintén a tárgyalásokat folytatott a Magrebben. Az amerikai diplomaták például 1797/1799-ben kötöttek békeszerződést a Tuniszi Kormányzósággal. ${ }^{80}$ A szerződések ellenére több incidens is történt a felek között, míg végül Tripoli hadat üzent az Egyesült Államoknak 1801-ben. A Jefferson-adminisztráció volt az, mely a század elején több flottát is küldött Tripoliba, hogy véget vessen az amerikaiak rabszolgaságának és a váltságdíj-fizetések rendszerének. ${ }^{81}$

A napóleoni háborúkat követően a nyugat-európai államok egyre keményebben léptek fel a muszlim és keresztény kalózokkal szemben. ${ }^{82}$ Egyrészt az 1815 és az 1816 közötti időszakban, az úgynevezett második barbár háború során az amerikai flotta harcolt az algíri kalózokkal. Emellett 1816-ban az egyesült angol-holland flotta Edward Pellew, Exmouth grófának (1757-1833) vezetésével vette fel a küzdelmet a muszlim kalózokkal, és lőtte Algír városát. A bombázás eredményeképpen a magrebi városoknak jóvátételt kellett fizetniük, fel kellett hagyniuk a kalózkodással, és szabadon kellett bocsátaniuk a keresztény rabokat. ${ }^{83}$

\footnotetext{
78 Augsburgi liga háborúja (1688-1697), spanyol örökösödési háború (1701-1713/14)

79 Groот 1985. 143.

80 IRWIN 1931. 69-91.

81 Allen 1905. 88-266.; Fremont-Barnes 2006. 39-63.; KitZen 1993. Az Egyesült Államok magrebi politikájához, és a muszlimok politikai, katonai és kulturális hatásaira a fiatal Köztársaságra lásd LAMBERT 2005.; Palotás 2015.

${ }^{82}$ Napóleon már 1798-ban elfoglalta a keresztény kalózkodás központjának számító Málta szigetét. NAYLOR: 2009. 123.; TESTA 1997.

83 Az 1815-1816-os eseményekhez lásd Lane-Poole 1890. 292-300.; PanZaC 2005. 259-292.; Fremont-Barnes 2006. 76-85.; ALLEN 1905. 281-302.; LeINER 2006.
} 


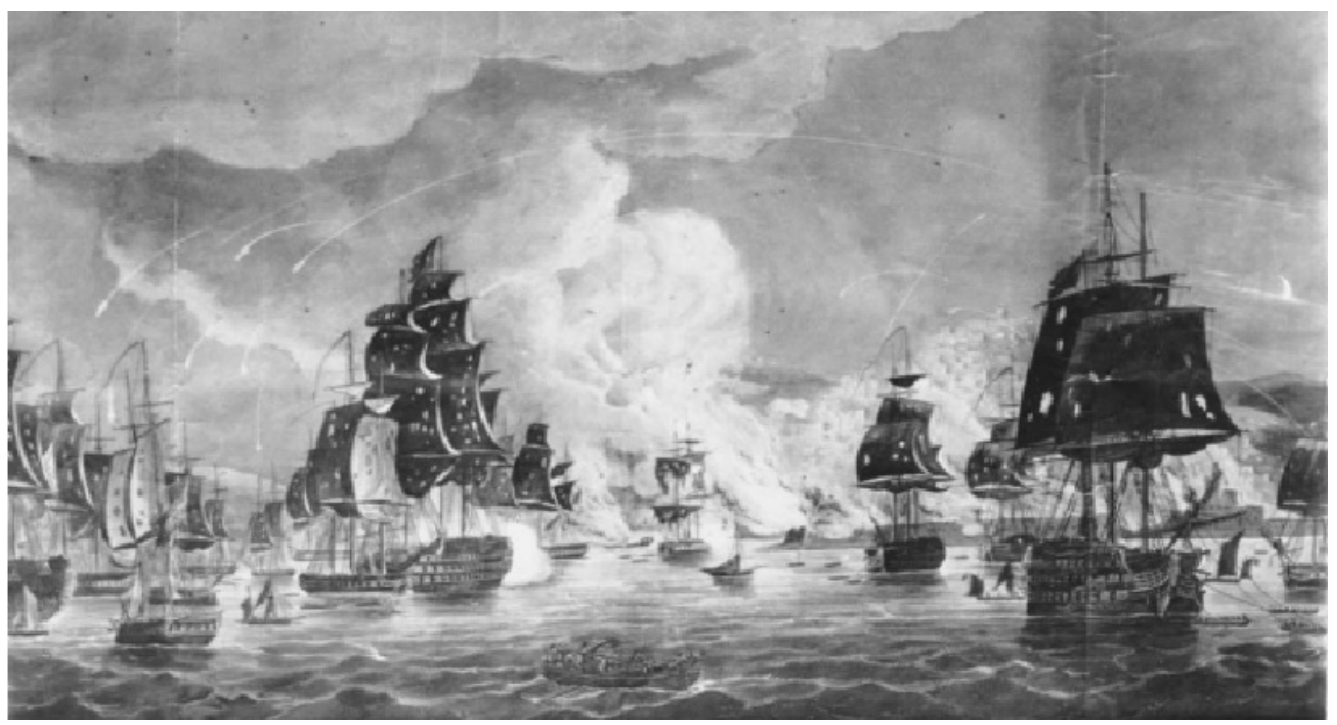

5. ÁBRA Lord Exmouth flottája az éjszaka során Algírt bombázza 1816-ban. (PANZAC 2005. 285.)

Az észak-afrikai kalózkodás és az oszmánok uralmának végére (kivéve Tripolit, melyet az olaszok foglaltak el 1911-ben) a franciák tettek pontot. A francia monarchia ugyanis X. Károly uralkodása alatt (1824-1830) először Algírt annektálta 1830-ban, majd 51 évvel később, 1881-ben protektorátusává szervezte Tunéziát. (5. ÁBRA)

\section{Konklúzió}

Összefoglalásképpen kijelenthető, hogy az oszmán észak-afrikai területek és a nyugat-európai államok élénk politikai és gazdasági kapcsolat tartottak fenn a 17. században. A különböző nyugati renegátok tevékenységének és paradox módon a kalózkodásnak köszönhetően Észak-Afrika bekapcsolódott a modern világgazdasági rendszerbe. Emellett a muszlimokés a keresztények a Földközi-tenger nyugati medencéjében egymás mellett éltek és kapcsolatban voltak egymással. A 17. századot megelőző időszakkal szemben, a mediterrán világ ezen térsége nem az iszlám és a keresztény kultúra elkülönülő halmaza - oszmán-spanyol szembenállás -, hanem egymással kapcsolatban álló és - a rabok kiváltása révén - érintkező egységes kultúra volt.

A nyugat-európai és a Magreb-államok közötti viszony nem volt mindig felhőtlen és gyakoriak voltak a muszlim kalózkodás miatt kialakult konfliktusok. A 17. század végére és a 18. század elejére Angliának, Franciaországnak és Hollandiának sikerült helyreállítania a kapcsolatait az oszmán kormányzóságokkal Észak-Afrikában. A hollandok a békés, tárgyalásos megoldást részesítették előnyben, és elfogadták általában azt, hogy rendszeresen adóval megváltsák a békét. Anglia ezzel szemben a fegyveres megoldást választotta érdekei védelmében. Tizennégy hónap leforgása alatt az angol tengerészet elsüllyesztett 30 kalózhajót, ami elég volt ahhoz, hogy a kormányzóságokkal megkössék a békeszerződéseket. Franciaország még az angoloknál is brutálisabb utat választott a kalózkérdés megoldására. A század végén az Algír és a Tunisz ellen indított hadmüveletek ugyanis inkább voltak városostromok, mint tengeri csaták. 
A nyugati államok katonai fölénye, különösen a század végén nagyságrendekkel nagyobb volt az észak-afrikai városok katonai erejénél. A muszlim államok, ahogyan azt Daniel Panzac is kitűnően megfogalmazta azonban felismerték, hogyan használják ki a rivalizálást a nyugati államok között, és hogyan húzzanak hasznot a nemzetközi eseményekből (például napóleoni háborúk időszaka). ${ }^{84}$ Amíg a nyugati államok meg nem erősödtek a 18. században, addig fontosnak tartották a kétoldalú kapcsolat fenntartását észak-afrikai területekkel. A 19. század ezzel szemben a muszlim államok hanyatlásának időszak, melynek nyitánya Algír amerikai, angol és holland bombázásai, majd franciák által történő elfoglalása volt.

\section{Melléklet}

\section{SZERZŐDÉSEK OSZMÁN ÉSZAK-AFRIKA ÉS A NYUGAT-EURÓPAI ÁLLAMOK KÖZÖTT (1605-1704)}

\begin{tabular}{|c|c|c|c|}
\hline DÁtum & Algír & TUNISZ & TRIPOLI \\
\hline $\begin{array}{l}1626 \\
1628 \\
1640 \\
1658 \\
1660 \\
1662 \\
1665 \\
1666 \\
1668 \\
1672 \\
1673 \\
1676 \\
1679 \\
1681 \\
1682 \\
1683 \\
1684 \\
1685 \\
1686 \\
1689 \\
1693 \\
1699 \\
1703 \\
1704\end{array}$ & $\begin{array}{c}\text { Hollandia } \\
\text { Hollandia } \\
\text { Anglia } \\
\text { Hollandia } \\
\text { Franciaország } \\
\text { Franciaország } \\
\text { Anglia } \\
\text { Anglia } \\
\text { Hollandia } \\
\text { Franciaország } \\
\text { Anglia } \\
\text { Anglia } \\
\text { Hollandia } \\
\text { Anglia } \\
\text { Franciaország } \\
\text { Anglia } \\
\text { Franciaország } \\
\text { Anglia } \\
\text { Hollandia }\end{array}$ & $\begin{array}{c}\text { Franciaország } \\
\text { Hollandia } \\
\text { Hollandia } \\
\text { Anglia } \\
\text { Hollandia } \\
\text { Franciaország } \\
\text { Franciaország } \\
\end{array}$ & $\begin{array}{c}\text { Anglia } \\
\text { Anglia } \\
\text { Anglia } \\
\text { Franciaország } \\
\text { Hollandia } \\
\text { Franciaország } \\
\text { Franciaország } \\
\text { Hollandia }\end{array}$ \\
\hline
\end{tabular}

Forrás: PANZAC 2005. 335. (A tanulmányban említett szerzödések dátumai félkövérrel szerkesztve [P. ZS.])

84 PANZaC 2005. 35. 


\section{FELHASZNÁLT IRODALOM}

Abun-NaSR, JAmil M. (1971): A History of the Maghrib. Cambridge, Cambridge University Press.

Allen, Gardner Weld (1905): Our Navy and the Barbary Corsairs. Boston, MA - New York, NY Chicago, IL, Houghton Mifflin and Company.

Anderson, R. C. (1952): Naval Wars in the Levant, 1559-1853. Liverpool, University Press.

Andrews, Kenneth R. (1964): Elizabethan Privateering during the Spanish War, 1585-1603. Cambridge, Cambridge University Press.

Blondy, Alain (2003): Bibliographie du monde méditerranéen: Relations et échanges (1453-1835). Paris, Presse de l'Université de Paris-Sorbonne.

Bono, SALVATORE (1964): I corsari barbareschi. Torino, ERI-Edizion RAI Radiotelevisione Italiana.

Bono, Salvatore (1993): Naval Exploits and Privateering. In Hospitaller Malta. 351-397.

Bono, Salvatore (2000): Les Corsaires en Méditerranée. Paris, Éditions La Porte.

Bono, Salvatore (2009): Piraten und Korsaren im Mittelmeer. Seekrieg, Handel und Sklaverei vom 16. bis 19. Jahrhundert. Stuttgart, Klett-Cotta.

Boogert, MaUrTis H. van DEN (2005): The capitulations and the Ottoman legal system. Qadis, consuls and beraths in the $18^{\text {th }}$ century. Leiden - Boston, MA, Brill.

BoubAKER, SADOK (1987): La Régence de Tunis au XVII siècle: ses relations commerciales avec les ports de l'Europe méditerranéenne, Marseille et Livourne. Zaghouan, Ceroma.

Bousquet, G. H. - Bousquet-Mirandolle, G. W. (1957): Thomas Hees. Journal d'un voyage à Alger (1675-1676). Revue Africaine. Vol. 101. 85-128.

Braudel, Fernand (1996): A Földközi-tenger és a mediterrán világ II. Fülöp korában [La Méditerranée et le monde méditerranéen a l'époque de Philippe II]. 1-3 kötet, Budapest, Akadémia Kiadó.

Bryson, Thomas A. (1979): American Diplomatic Relations with the Middle East, 1784-1975. An Annotated Bibliography. London - Metuchen, NJ, Scarecrow Press, Inc.

CARD, E. Rouard DE. (1906): Traités de la France avec les Pays de l'Afrique du Nord: Algérie, Tunisie, Tripolitanie, Maroc. Paris, A. Pédone, Éditeur.

Cassar, Paul (1960): The Maltese Corsairs and the Order of St. John of Jerusalem. The Catholic Historical Review. Vol. 46. No. 2. 137-156.

Cavaliero, Roderic E. (1959): The Decline of the Maltese Corso in the XVIIIth century. A study in maritime history. Melita Historica Vol. 2. No. 1. 224-238.

Chalmers, George (1790): A Collection of Treaties Between Great Britain and Other Powers. 2 vols., London, Printed for J. Stockdale, Piccadilly.

Chérif, Mohamed Hedi (1999): Algeria, Tunisia and Libya. The Ottomans and their hiers. In General History of Africa. 233-261.

Coindreau, Roger (1948): Les Corsaires de Salé. Paris, Société d'éditions géographiques, maritimes et coloniales.

Corbett, Julian Stafford (1899): Drake and the Tudor Navy: History of the Rise of England as a Maritime Power. 2 vols., New York, NY, Burt Franklin.

Corbett, Julian StAFFord (1904): England in the Mediterranean. A Study of the Rise and Influence of British Power within the Straits 1603-1713. 2 vols., London, Longmans, Green, and Co.

Crowley, Roger (2014): Tengeri birodalmak. A kereszténység és az iszlám harca a Földközi-tenger feletti uralomért (1521-1580) [Empires of the Sea. The Final Battle for the Mediterranean, 1521-1580]. Budapest, Park Könyvkiadó.

Dan, Pierre (1646): Histoire de la Barbarie et de ses corsaires, des royaumes, et des villes d'Alger, de Tunis, de Salé, \& de Tripoly: divisée en six livres où il est traité de leur gouvernement, de leurs moeurs, de leur cruautés, de leurs brigandages, de leurs sortilèges, \& de plusieurs autres particularités remarquables. Ensemble des grandes misères et des cruels tourments qu'endurent les chrétiens captifs parmi ces infidèles. Paris, Chez Pierre Rocolet.

Dan, Pierre (1684a): Historie van Barbaryen en des zelfs zee-roovers. Behelzende een befchrijving van de Koningrijken en Steden Algiers, Tunis, Salé, en Tripoli... in't Fransch beschreeven... en in't Nederduitsch gebracht door G. Van Broekhuizen. Amsterdam, Jan ten Hoorn. 
DAN, Pierre (1684b): Illustrations de Historie van Barbaryen en des Zelfs zee-roovers. http://gallica. bnf.fr/ark:/12148/btvlb2000020m. Hozzáférés: 2015.07.15.

Davis, Robert C. (2001): Counting European Slaves on the Barbary Coast. Past and Present. Vol. 172. 87-124. Davis, Robert C. (2003): Christian Slaves, Muslim Masters. White Slavery in the Mediterranean, The Barbary Coast, and Italy, 1500-1800. New York, NY, Palgrave Macmillan.

Deed of Donation of the Maltese Islands to the Order of St. John of Jerusalem by Emperor Charles $V$ in 1530 (2011). National Library of Malta.

EARLE, Peter (1970): Corsairs of Malta and Barbary. London, Sidgwick and Jackson, Ltd.

Eeghen, Pieter van (1905): Het Werk van Jan en Casper Luyken, door P. Van Eeghen, met medewerking van J. Ph. Van der Kellen,... 2 vols., Amsterdam, Frederik Muller \& Co.

Eickhoff, EккенаRd (2010): Velence, Bécs és a törökök. A nagy átalakulás Délkelet-Európában (1645-1700) [Venedig, Wien und die Osmanen: Umbruch in Südosteuropa, 1645-1700]. Budapest, Európa Könyvkiadó.

Fisher, Godfrey (1957): Barbary Legend. War, Trade and Piracy in North Africa, 1415-1830. Oxford, Clarendon Press.

Fremont-BARnes, Gregory (2006): The Wars of the Barbary Pirates. To the Shores of Tripoli: the Rise of the US Navy and Marines. Oxford, Osprey Publishing Ltd.

GLETE, JAN (2000): Warfare at Sea, 1500-1650. Maritime conflicts and the transformation of Europe. London, Routledge.

Greene, Molly (2010): Catholic Pirates and Greek Merchants. A Maritime History of the Mediterranean. Princeton, NJ, Princeton University Press.

Groot, Alexander H. DE (1985): Ottoman North Africa and the Dutch Republic in the Seventeenth and Eighteenth Centuries. Revue de l'Occident musulman et de la Mèditerranèe. No. 39. 131-147.

Guilmartin, John Francis (1974): Gunpowder and Galleys. Changing Technology and Mediterranean Warfare at Sea in the $16^{\text {th }}$ Century. London - New York, NY, Cambridge University Press.

HeEringa, K. (ed.) (1910, 1917): Bronnen tot de Geschiedenis van den Levantschen Handel 1590-1660, 1661-1726. 2 vols., 's-Gravenhage (The Hague), M. Nijhoff.

Hess, Andrew C. (1972): The Battle of Lepanto and its Place in Mediterranean History. Past and Present. Vol. 57. 53-73.

Irwin, Ray Watkins (1931): The Diplomatic Relations of the United States with the Barbary Powers, 1776-1816. Chapel Hill, NC, The University of North Carolina Press.

Karman, GÁbor - KunčEvić, Lovro (eds.) (2013): The European tributary states of the Ottoman Empire in the sixteenth and seventeenth centuries. Leiden - Boston, MA, Brill.

Kitzen, Michael L. S. (1993): Tripoli and the United States at War. A History of American Relations with the Barbary States, 1785-1805. London - Jefferson, NC, McFarland \& Company, Inc.

Konstam, Angus (2003): Lepanto 1571. The greatest naval battle of the Renaissance. Oxford, Osprey Publishing Ltd.

Krieken, Gérard VAN (1993): Renégats néerlandais en Afrique du Nord aux XVIIe et XVIIIe siècles. Cahiers de Tunisie. Vol. 46. 49-63.

Lambert, Frank (2005): The Barbary Wars. American Independence in the Atlantic World. New York, NY, Hill and Wang.

Lane-Poole, Stanley (1890): The Barbary Corsairs. New York, NY, G. P. Putnam's Sons.

Leiner, C. Frederick (2006): The End of Barbary Terror. America's 1815 war against the Pirates of North Africa. Oxford, Oxford University Press.

Lewis, Bernard (1973): Corsairs in Iceland. Revue de l'Occident musulman et de la Mèditerranèe. No. 15-16. 139-144.

Lloyd, Christopher (1981): English Corsairs on the Barbary Coast. London, Collins.

LuYKen, JAN (1698): Tijdens het bombardement van Algiers door de Franschen wordt de daar aanwezige Fransche Consul door de Algerijnen in een kanon geladen en alzoo gedood. https://commons. wikimedia.org/wiki/File:Supplice_du_consul_de_france_pere_levacher.JPG Hozzáférés: 2015.07.15.

Mallia-Milanes, Victor (1992): Venice and Hospitaller Malta, 1530-1798. Aspects of a Relationship. Marsa (Malta), Publisher Enterprises Group, Ltd. 
Mallia-Milanes, Victor (ed.) (1993): Hospitaller Malta, 1530-1798. Studies on Early Modern Malta and the Order of St John of Jerusalem. Msida (Malta), Minerva Publications 1993.

Masson, Paul (1897): Histoire du commerce français dans le Levant au XVII esiècle. Paris, Hachette. Muscat, Joseph (1997): The Maltese Corso. In Méditerranée, mer ouverte. 191-236.

Naylor, Philip Chiviges (2009): North Africa. A History from Antiquity to the Present. Austin, TX, University of Texas Press.

Nicholson, Helen (2001): The Knights Hospitaller. Woodbridge, The Boydell Press.

Ogot, B. A. (ed.) (1999): General History of Africa. Volume 5. Africa from the Sixteenth to the Eighteenth Century. Berkeley, CA, University of California Press.

Palotás Zsolt (2011): Improvisation and directive. Development of naval warfare tactics in the AngloDutch Wars (1652-1674). In J. Nagy László (dir.): Mediterrán Tanulmányok XX. Szeged, JATEPress. 2011. 17-28.

Palotás Zsolt (2015): Political, Military and Cultural Impact of the North African Muslims on the United States during the first years of the Early Republic, 1783-1807. In J. Nagy László (dir.): Mediterrán Tanulmányok XXIV. Szeged, JATEPress. 19-40.

Palotás Zsolt (2017): Bejek, korzárók és diplomaták. A Tuniszi Kormányzóság kapcsolatai a nyugateurópai államokkal és az Egyesült Államokkal, 1605-1830. Doktori értekezés (kézirat), Szegedi Tudományegyetem, Szeged.http://doktori.bibl.u-szeged.hu/3289/1/Palotas\%20Zsolt_ertekezes.pdf Hozzáférés: 2017.08.04.

PAnZAC, DAniel (2005): Barbary Corsairs. The End of a Legend 1800-1820 [Les corsaires barbaresques: La fin d'une épopée, 1800-1820]. Leiden - Boston, MA, Koninklijke Brill.

Pennell, C. Richard (1998): Who Needs Pirate Heroes? The Northern Mariner/Le Marin du nord. Vol. 8. No. 2. 61-79.

Pennell, C. Richard (ed.) (1989): Piracy and Diplomacy in the Seventeenth-Century North Africa. The Journal of Thomas Baker, English Consul in Tripoli, 1677-1685. London, Associated University Press.

Playfair, Robert Lambert (1884): The Scourge of Christendom. Annals of British Relations with Algiers Prior to the French Conquest. London, Smith, Elder, \& Co.

RANG, SANDER - Denis, Ferdinand (1837): Fondation de la régence d'Alger. Histoire des Barberousse, chronique arabe du XVI siècle. Publié sur un manuscrit de la Bibliothèque royale, avec un appendice et des notes. Expédition de Charles-Quint; Aperçu historique et statistique du port d'Alger. 2 tome, Paris, J. Angé.

Rasor, Eugene L. (2004): English/British Naval History to 1815. A Guide to the Literature. Westport, CT, Praeger Publishers.

Rothenberg, Gunther E. (1961): Venice and the Uskoks of Senj: 1537-1618. The Journal of Modern History. Vol. 33. No. 2. 148-156.

Ryan, Anthony M. (1999): Isten kalóza: Francis Drake. In Admirálisok. 29-45.

Sire, H. J. A. (1994): The Knights of Malta. New Haven, CT, Yale University Press.

SPencer, William (1976): Algiers in the Age of Corsairs. Norman, OK, University of Oklahoma Press.

SweEtman, JACK (ed.) (1999): Admirálisok. A történelem legkiválóbb tengernagyai: 1587-1945 [The great admirals: command at sea, 1587-1954]. Budapest, Zrínyi Kiadó.

Tenenti, Alberto (1967): Piracy and the Decline of Venice 1580-1615. London, Longmans.

Testa, Carmel (1997): The French in Malta, 1798-1800. Valetta (Malta), Midsea Books, Ltd.

Villain-Gandossi, Christiane - Durteste, Louis - Busuttil, Salvino (dir.) (1997): Méditerranée, mer ouverte. Actes du Colloque de Marseille, 21-23 septembre 1995. Tome I. Malta, International foundation.

WoLf, John B. (1979): The Barbary Coast. Algiers under the Turks 1500-1830. New York, NY - London - Toronto, Norton - G. J. McLeod, cop. 